\title{
Effect of liming on cadmium immobilisation in the soil and content in spring wheat (Triticum aestivum $\mathbf{L}$.)
}

\author{
Ala Nagiel, Wiesław Szulc ${ }^{1, *}$ \\ 1 Warsaw University of Life Sciences - SGGW, Institute of Agriculture, Department of Agricultural Chemistry, ul. Nowoursynowska \\ 159, building no. 37, 02-776 Warszawa, Poland \\ * Prof. dr hab. W. Szulc, wiesław_szulc@sggw.edu.pl, ORCID iD: https://orcid.org/0000-0001-8505-0514
}

Received: January 24, 2020

Accepted: April 16, 2020

Associated editor: J. Antonkiewicz

\section{Keywords}

Spring Wheat

Cadmium

Grain

Straw

Yield

\begin{abstract}
The objective of the study was the determination of the efficiency of the liming process in terms of cadmium immobilisation in the soil and its uptake by spring wheat. The research was conducted on a microfield experiment established at the Experimental Station of the Institute of Agriculture in Skierniewice. The surface soil layer was contaminated with cadmium to the second degree of contamination according to Kabata-Pendias et al. (1993), i.e., $1.87 \mathrm{mg} \mathrm{Cd} \cdot \mathrm{kg}^{-1}$. The soil was subject to liming with $\mathrm{CaO}(60 \%)$ at doses according to $0,0.5,1.5$, and 2 hydrolytic acidity (Hh). In the experiment, the analysed crop was spring wheat (Mandaryn cultivar). Data showed that an increase in liming was accompanied by a decrease in the content of cadmium both in the grain and straw of wheat. The content of cadmium in wheat grain varied from $0.038 \mathrm{mg} \mathrm{Cd} \mathrm{kg}^{-1}(2 \mathrm{Hh})$ to $0.351 \mathrm{mg} \mathrm{Cd} \mathrm{kg}^{-1}(0 \mathrm{Hh})$. In the case of wheat straw, it ranged from $0.147 \mathrm{mg} \mathrm{Cd} \mathrm{kg}^{-1}$ (2 Hh) to $0.554 \mathrm{mg} \mathrm{Cd} \mathrm{kg}^{-1}(0 \mathrm{Hh})$. The content of cadmium in straw did not exceed the acceptable content of trace substances in fodders as stipulated in the Regulation of the Minister of Agriculture and Rural Development 2012.
\end{abstract}

\section{Introduction}

One of the elementary physicochemical properties of soil is its reaction, determining a number of factors such as: fertility and course of chemical and biochemical processes. They determine the ecological and phytosanitary function and is responsible for the regulation of nutrients uptake by plants. An increase in soil acidity changes the rate of a number of processes causing the release of heavy metals from the sorption complex to the soil solution (Przewocka, 2014). Soil reaction determines the form and bioavailability of heavy metals. Soil acidity affects the mobilisation or immobilisation of heavy metals (Kabata-Pendias and Pendias, 1999). In the case of very acidic and acidic soils, an increase in mobile forms of heavy metals in the soil solution occurs. This process is associated with the increase in solubility of chemical substances containing a given element, and simultaneously a decrease in their retention by soil colloids at low soil reaction (Yasir et al., 2018).

Soils with very acidic and acidic reaction are grouped to chemically degraded soils, where the biological life declines, including bacteria fulfilling an important function in the environment. The resulting gap in the ecosystem is occupied by fungi (Karczewska and Kabała, 2010).
Data reported by the Chief Inspectorate of Environmental Protection (website 1), point at the the following voivodeships as characterised by soils with the lowest pH: Mazowieckie, Świętokrzyskie, Łódzkie, Podlaskie, and Kujawsko-Pomorskie. Only soils at the Pomorskie, Lubuskie, and Lubelskie voivodeships could be classified as slightly acidic. Currently, liming is an efficient and commonly applied method for immobilising metals in the soil (Kamionka, 2010; Karczewska and Kabała, 2010; Dradrach et al. 2019). The application of calcium compounds $\left(\mathrm{CaCO}_{3}\right.$, and $\mathrm{CaO}$ ) increase the negative charge of soil particles and sorptive properties of soil and precipitation of metals in the form of carbonates or hydroxides (Krzyżak, 2013).

According to information of IUNG (Monitoring chemizmu... 2018), a decrease in the application of calcium fertilisers has been observed in recent years. Calcium doses were on average 90 $\mathrm{kg} \mathrm{CaO} \mathrm{ha}^{-1} \mathrm{year}^{-1}$, and deviated from the actual demand of soils for the compound. The cause of the situation could have been the revoking of subsidies for liming in 2004. The amount of calcium fertilisers supplied to soils did not cover the losses resulting from the ongoing natural processes (Przewocka, 2014). In terms of anthropogenic soil acidification related among others to the application of physiologically acidic fertilisers, the liming process should be systematic (Chief Inspectorate of Environmental Protection, 2018). 
The objective of the paper was the determination of the efficiency of the liming process in terms of cadmium immobilisation in the soil and limiting of its uptake by spring wheat.

\section{Material and methods}

The study was conducted on a microfield experiment established at the Experimental Station of the Institute of Agriculture of the Warsaw University of Life Science in Skierniewice in 2019. The analysed crop was spring wheat, the Mandaryn cultivar. Microfields were established in stoneware pipes with a height of $120 \mathrm{~cm}$ and diameter of $40 \mathrm{~cm}$ embedded in the ground, filled with soil reflecting the soil profile. The experiment was established on Luvisols (IUSS Working Group WRB, 2015) the agrotechnical properties of which are presented in Table 1. The surface soil layer $(0-25 \mathrm{~cm})$ was contaminated with cadmium (in the form of $\mathrm{CdSO}_{4} \square 8 \mathrm{H}_{2} \mathrm{O}$ as aqueous solution) to the second degree of contamination according to Kabata-Pendias et al. (1993), i.e., $1.87 \mathrm{mg}$ $\mathrm{Cd} \cdot \mathrm{kg}^{-1}$. A month after cadmium application, the soil was limed with calcium oxide with a $60 \%$ content of $\mathrm{CaO}$ in accordance with the following hydrolytic acidity: $0,0.5,1,1.5$, and $2 \mathrm{Hh}$. The experiment was conducted in three replications. Soil and plant samples were collected on 29.07.2019. Plant material (grain, straw) was ground on a grinder by Retsh at 5000 rounds per minute. The resulting plant material was subjected to mineralisation in a mixture of acids $\mathrm{HNO}_{3}$ and $\mathrm{HClO}_{4}$ in a volumetric ratio of $4: 1$. The content of cadmium was determined by means of the method of atomic absorption spectrometry (ASA). The soil samples after air drying were sieved through a $2 \mathrm{~mm}$ mesh. The content of total cadmium after dissolution of the soil in reverse aqua regia $\left(\mathrm{HCl}: \mathrm{HNO}_{3}\right.$ in a ratio of $\left.1: 3\right)$ and content of available $\mathrm{Cd}$ after extraction in a solution of $1 \mathrm{~mol} \mathrm{dm}^{-3} \mathrm{HCl}$ was determined by the ASA method. Soil reaction $(\mathrm{pH})$ was measured by of the potentiometric method in $1 \mathrm{~mol} \mathrm{dm}^{-3}$ solution (Table 1).

The statistical processing of results applied the multi-factor analysis of variance and the linear regression method. Tukey's

Table 1. Soil properties in experiment

\begin{tabular}{|c|c|c|c|c|c|c|}
\hline Gravel & Sand & Silt & Clay & $C_{\text {org }}$ & CEC & $\mathrm{Ca}_{\text {ex }}$ \\
\hline$\%$ & & & & $\mathrm{~g} \cdot \mathrm{kg}^{-1}$ & $\mathrm{cmol}(+) \cdot \mathrm{kg}^{-1}$ & \\
\hline 1 & 68 & 16 & 15 & 5.59 & 4.20 & 2.38 \\
\hline
\end{tabular}

test was applied for determining the significance of differences between mean values at a significance level $p=0.05$. The statistical analysis of results was performed with the application of Microsoft Excel and Statistica 13.1 Stat Soft Polska.

\section{Results and discussion}

Soil reaction considerably affected the yield of the test crop (Table 2). An increase in the liming dose was accompanied by higher yields in spring wheat grain. The yield varied from 650.8 to $759.8 \mathrm{~g} \mathrm{~m}^{-2}$. Liming also significantly affected the yield of straw.
Substantially higher yields in comparison to the control were obtained on the treatment of 1.5 and $2 \mathrm{Hh}$. Similarly, according to Zhang et al. (2018), soil reaction manifested a strong effect on the phytotoxicity of heavy metals. At a higher $\mathrm{pH}$, the toxic effect of cadmium decreased. Lower yields of wheat caused by heavy metals are a consequence of their phytotoxic effect. It is manifested in a lower content of chlorophyll in plant tissues, lower photosynthetic, respiration, and transpiration activity, resulting in the inhibition of their growth (Czeczot and Majewska, 2010; Vaverková and Adamcová, 2014).

The current research showed that the content of cadmium in wheat grain growing on all the contaminated treatments was lower as compared to the control. Cadmium content both in grain and straw decreased with an increase in the dose of CaO (Table 3).

Similar dependencies were obtained by Xiao et al. (2017), who evidenced that combined application of liming and phosphorus

Table 2. Yield of spring wheat depending on liming and soil pollution by cadmium

\begin{tabular}{llll}
\hline Treatment & & Grain & Straw \\
\cline { 1 - 2 } Hh & & $\mathrm{g} \cdot \mathrm{m}^{-2}$ & \\
0 & $653.0^{\mathrm{a}}$ & $403.0^{\mathrm{a}}$ \\
0.5 & $650.8^{\mathrm{a}}$ & $393.6^{\mathrm{a}}$ \\
1.0 & $691.8^{\mathrm{a}}$ & $419.0^{\mathrm{a}}$ \\
1.5 & $758.3^{\mathrm{b}}$ & $463.0^{\mathrm{b}}$ \\
2.0 & $759.8^{\mathrm{b}}$ & $523.6^{\mathrm{c}}$ \\
\hline
\end{tabular}

a-c-mean values marked with the same letters do not differ significantly at the $\mathrm{p}=0.05$

fertilisation permits a reduction of the content of cadmium in rice grain by even $85 \%$. They simultaneously observed a decrease in the content of available forms of cadmium in the soil by more than $16 \%$ in comparison to the treatment without liming. Also

Table 3. Cadmium content in wheat grain and straw

\begin{tabular}{|c|c|c|}
\hline Treatment & Grain & Straw \\
\hline $\mathrm{Hh}$ & \multicolumn{2}{|c|}{$\mathrm{mg} \mathrm{Cd} \cdot \mathrm{kg}^{-1}$} \\
\hline 0 & $0.351^{\mathrm{d}}$ & $0.554^{\mathrm{d}}$ \\
\hline 0.5 & $0.227^{\mathrm{c}}$ & $0.357^{c}$ \\
\hline 1.0 & $0.094^{b}$ & $0.238^{\mathrm{b}}$ \\
\hline 1.5 & $0.092^{b}$ & $0.231^{\mathrm{b}}$ \\
\hline 2.0 & $0.038^{\mathrm{a}}$ & $0.147^{\mathrm{a}}$ \\
\hline
\end{tabular}

a-d - mean values marked with the same letters do not differ significantly at the $\mathrm{p}=0.05$

Malinowska (2017) evidenced a strong decrease in availability of metals as a result of liming. Similar changes were observed by Tlustoš et al. (2006), who obtained a 50\% decrease in the content of cadmium in the soil as a result of liming in comparison to the control, simultaneously observing a decrease in the content of the element both in the roots and above-ground parts (straw and grain) of wheat. Karalić et al. (2013) reported that liming caused 
the strongest effect of reduction of the content of available forms of metals ( $\mathrm{Zn}, \mathrm{Pb}, \mathrm{Cr}$, and $\mathrm{Cd}$ ) in extremely acidic soils with the highest initial available concentrations. On the other hand, the weakest relative effect of liming on a decrease in availability of heavy metals was recorded in moderately acidic soils with the lowest initial concentrations of available heavy metals.

Chamon et al. (2005) pointed out that in addition to liming, also an addition of organic substance and iron compounds (by-product of the aluminium industry) additionally limits the content of available forms of metals such as $\mathrm{Zn}, \mathrm{Ni}, \mathrm{Cd}$, and $\mathrm{Cr}$. Research by Antonkiewicz et al. (2018) also shows that waste materials primarily containing calcium compounds supplied to the soil can reduce the mobility of heavy metals.

In this research, the content of cadmium in grain and straw did not exceed the maximum acceptable content (1 mg Cd kg-1) in fodders as stipulated by the Ministry of Agriculture and Rural Development (Dz.U. poz. 203., 2012). Symanowicz et al. (2015) shows that nitrogen fertilization influenced on concentrations of the selected heavy metals (except for $\mathrm{Pb}$ and $\mathrm{Cd}$ ) were within the permissible limits for trace elements in feedstuffs specified by Polish and European standards.

The showed that the content of available and total forms of cadmium significantly decreased in the entire range of liming (Table 4), which limited the occurrence of both forms of cadmium the strongest at the dose of $2 \mathrm{Hh}$. The content of total cadmium form, on all the analysed treatments did not exceed the acceptable content in the soil or ground of agricultural and forest land (3 mg Cd kg-1), (Dz.U. poz. 1395., 2016 ). An increase in the dose of $\mathrm{CaO}$ was accompanied by a decrease in the soil content of

Table 4. Content of total and available forms of cadmium in soil and pH

\begin{tabular}{|c|c|c|c|c|}
\hline Treatment & $\begin{array}{l}\text { Total } \\
\text { forms }\end{array}$ & $\begin{array}{l}\text { Available } \\
\text { forms }\end{array}$ & $\begin{array}{l}\text { Share of available } \\
\text { into total forms }\end{array}$ & \\
\hline $\mathrm{Hh}$ & $\mathrm{mg} \mathrm{Cd} \cdot \mathrm{kg}^{-1}$ & & $\%$ & $\mathrm{pH}$ \\
\hline 0 & $1.597^{\mathrm{c}}$ & $1.264^{\mathrm{c}}$ & 79.1 & 5.95 \\
\hline 0.5 & $1.779^{d}$ & $1.301^{\mathrm{c}}$ & 73.1 & 6.79 \\
\hline 1.0 & $1.462^{\mathrm{b}}$ & $1.227^{\mathrm{c}}$ & 83.9 & 7.38 \\
\hline 1.5 & $1.426^{b}$ & $0.951^{b}$ & 66.7 & 7.25 \\
\hline 2.0 & $1.216^{\mathrm{a}}$ & $0.645^{\mathrm{a}}$ & 53.0 & 7.63 \\
\hline
\end{tabular}

$\mathrm{a}-\mathrm{d}-$ mean values marked with the same letters do not differ significantly at the $\mathrm{p}=0.05$ forms extractable with hydrochloric acid at the concentration of $1 \mathrm{~mol} \mathrm{dm}^{-3}$ The percent share of Cd extractable in $1 \mathrm{~mol} \mathrm{dm}^{-3}$ $\mathrm{HCl}$ to total content of cadmium was varied depending on the treatment (Table 4). The highest share of the available form to total form exceeded $83 \%$ and was occurred on the treatment $1 \mathrm{Hh}$. Because the share of the available form to total form varied from 53 to $83.9 \%$, it can be concluded that $1 \mathrm{~mol} \mathrm{dm}^{-3} \mathrm{HCl}$ is a very strong extraction solution.

For the purpose of analysis of the dependency between the soil properties and yield of wheat and cadmium content in grain and straw, the correlation analysis was performed (Table 5).

The analysis showed significant correlations between the soil properties. The strongest correlation was observed between the content of cadmium in straw and soil $\mathrm{pH}(\mathrm{r}=-0.89)$. Strong positive correlations were also found for the yield of straw and grain of wheat depending on soil $\mathrm{pH}$, where coefficients of correlation were 0.55 and 0.58 , respectively. This means, that an increase in $\mathrm{pH}$ in soil was accompanied with a significant increase in crop yields.

\section{Conclusions}

(1) Liming increased yields of spring wheat throughout the range of $\mathrm{CaO}$ doses.

(2) Liming was a treatment considerably limiting the uptake of cadmium and its content both in straw and grain of wheat. The contents did not exceed the acceptable level of cadmium in fodders as stipulated by the Regulation of the Minister of Agriculture and Rural Development.

(3) Soil liming at least according to 1.5 hydrolytic acidity significantly reduces the content of available forms of cadmium in the soil by approximately $50 \%$ as compared to the unlimed treatment.

\section{References}

Antonkiewicz, J., Pełka, R., Bik-Małodzińska, M., Żukowska, G., Gleń-Karolczyk, K., 2018. The effect of cellulose production waste and municipal sewage sludge on biomass and heavy metal uptake by a plant mixture. Environmental Science and Pollution Research 25, 31101-31112.

Chamon, A. S., Gerzabek, M. H., Mondol, M. N., Ullah, S. M., Rahman, M., Blum, W. E. H., 2005. Influence of soil amendments on heavy metal

Table 5. Simplified correlation matrix showing the relationships between the features

\begin{tabular}{|c|c|c|c|c|c|c|c|}
\hline & $\mathrm{pH}$ & $\begin{array}{l}\text { Available } \\
\text { forms }\end{array}$ & $\begin{array}{l}\text { Total } \\
\text { forms }\end{array}$ & $\begin{array}{l}\text { Cadmium- } \\
\text { content } \\
\text { in grain }\end{array}$ & $\begin{array}{l}\text { Cadmium- } \\
\text { content } \\
\text { in straw }\end{array}$ & $\begin{array}{l}\text { Grain } \\
\text { yield }\end{array}$ & $\begin{array}{l}\text { Straw } \\
\text { yield }\end{array}$ \\
\hline $\mathrm{pH}$ & 1 & & & & & & \\
\hline Available forms & $-0.62 *$ & 1 & & & & & \\
\hline Total forms & $-0.54^{*}$ & $0.65^{*}$ & 1 & & & & \\
\hline Cadmium content in grain & -0.33 & 0.43 & 0.33 & 1 & & & \\
\hline Cadmium content in straw & $-0.89^{*}$ & $0.65^{*}$ & 0.45 & 0.42 & 1 & & \\
\hline Grain yield & $0.55^{*}$ & $-0.75^{*}$ & $-0.79 *$ & -0.31 & -0.41 & 1 & \\
\hline Straw yield & $0.58^{*}$ & $-0.65^{*}$ & $-0.46^{*}$ & -0.37 & $-0.62 *$ & $0.63^{*}$ & 1 \\
\hline
\end{tabular}

* statistically significant values 
accumulation in crops on polluted soils of Bangladesh. Communications in Soil Science and Plant Analysis 36, 7-8, 907-924. https://doi. org/10.1081/CSS-200049472

Czeczot, H., Majewska, M., 2010. Kadm - zagrożenie i skutki zdrowotne (Cadmium - exposure and its effects on health). Toksykologia 66(4), 243-250.

Dradrach, A., Szopka, A., Karczewska, A. 2019. Ecotoxicity of pore water in soils developed on historical arsenic mine dumps: The effects of forest litter. Ecotoxicology and Environmental Safety, 181, 202-213. https://doi.org/10.1016/j.ecoenv.2019.05.079

IUSS Working Group WRB, 2015. World reference base for soil resources 2014, update 2015. International soil classification system for naming soils and creating legends for soil maps. World soil resources reports no. 106. FAO, Rome. http://www.fao.org/3/i3794en/I3794en.pdf

Karalić, K., Lončarić, Z., Popović, B., Zebec, V., Kerovec, D., 2013. Liming effect on soil heavy metals availability. Poljoprivreda 19(1), 59-64.

Kabata-Pendias, A., Pendias, H., 1999. Biogechemistry of trace elements. Wyd. Nauk. PWN, Warszawa, pp. 398.

Kabata-Pendias, A., Motowicka-Terelak, T., Piotrowska, M., Terelak, H., Witek, T., 1993. Assessment the degree of soil and plant pollution with heavy metals and sulphur. Framework guidelines for agriculture. Puławy, series P. (53), IUNG, pp. 20 (in Polish).

Kamionka, J., 2010. Analiza kosztów wapnowania gleb w Polsce (Analysis of the costs of liming the soils in Poland). Problemy Inżynierii Rolniczej 18(2), 25-30.

Karczewska, A., Kabała, C., 2010. Gleby zanieczyszczone metalami ciężkimi i arsenem na Dolnym Śląsku - potrzeby i metody rekultywacji (The soils polluted with heavy metals and arsenic in Lower Silesia the need and methods of reclamation), Zeszyty Naukowe Uniwersytetu Przyrodniczego we Wrocławiu Rolnictwo XCVI, 576, 59-80.

Krzyżak, J., 2013. Wspomagana fitostabilizacja metali ciężkich w glebach (Aided phytostabilization of heavy metals in soils). Praca doktorska, Instytut Inżynierii Ochrony Środowiska, Politechnika Wrocławska, 2013.

Malinowska, E., 2017. The Effect of Liming and Sewage Sludge Application on Heavy Metal Speciation in Soil. Bull EnvironContamToxicol 98(1), 105-112.

Rozporządzenie Ministra Rolnictwa i Rozwoju Wsi z dnia 6 lutego 2012 r. w sprawie zawartości substancji niepożądanych w paszach (Regula- tion of the Minister of Agriculture and Rural Development of 6 February 2012 regarding the content of undesirable substances in feed) (Dz.U. 2012 poz. 203).

Rozporządzenie Ministra Środowiska z dnia 1 września 2016 roku w sprawie sposobu prowadzenia oceny zanieczyszczenia powierzchni ziemi (Regulation of the Minister of the Environment of September 1, 2016 on the method of conducting soil surface pollution assessment) (Dz.U. 2016. poz. 1395). http://isap.sejm.gov.pl/DetailsServlet?id=WDU20160001395

Symanowicz, B., Kalembasa, S., Jaremko, D., Niedbała, M., 2015. Effect of nitrogen application and year on concentration of $\mathrm{Cu}, \mathrm{Zn}, \mathrm{Ni}, \mathrm{Cr}, \mathrm{Pb}$ and $\mathrm{Cd}$ in herbage (Galega orientalis Lam.). Plant Soil Environment 61(1): 11 - 16. https://doi.org/10.17221/558/2014-PSE

Tlustoš, P., Száková, J., Kořínek, K., Pavlíková, D., Hanč, A., Balík, J. 2006. The effect of liming on cadmium, lead, and zinc uptake reduction by spring wheat grown in contaminated soil, Plant Soil and Environment 52(1), 16-24. https://doi.org/10.17221/3341-PSE

website 1 https://www.gios.gov.pl.

Wiech, A., Marciniewicz-Mykiety, M., Toczko, B., 2018. Stan Środowiska w Polsce Raport (State of the Environment in Poland. Report), Biblioteka Monitoringu Środowiska, 166-169.

Vaverková, M., Adamcová, D., 2014. Heavy Metals Uptake by Select Plant Species in the Landfill Area of Štěpánovice, Czech Republic. Polish Journal of Environmental Studies 23, 2265-2269. https://doi. org/10.15244/pjoes/26106

Xiao, R., Huang, Z., Li, X., Chen, W., Deng, Y., Han, C., 2017. Lime and Phosphate Amendment Can Significantly Reduce Uptake of $\mathrm{Cd}$ and $\mathrm{Pb}$ by Field-Grown Rice. Sustainability 9, 430-440. https://doi.org/10.3390/ su9030430

Zhang, Y., Zhang, H., Zhang, Z., Liu, C., Cuizhen, C., Zhang, W., Marhaba, T., 2018. pH Effect on Heavy Metal Release from a Polluted Sediment. Journal of Chemistry, ID 7597640: 1-7. https://doi. org/10.1155/2018/7597640

Yasir Hamid, Y., Tang, L., Wang, X., Hussain, B., Yaseen, M.Z., Yang X., 2018. Immobilization of cadmium and lead in contaminated paddy field using inorganic and organic additives. Scientific Reports, 1-10. doi: 10.1038/s41598-018-35881-8

\section{Słowa kluczowe}

Pszenica jara

Kadm

Ziarno

Słoma

Plon

\section{Wpływ wapnowania na unieruchamianie kadmu w glebie oraz na jego zawartość w pszenicy jarej (Triticum aestivum L.)}

\section{Streszczenie}

Celem badań było określenie skuteczności procesu wapnowania, na unieruchamianie kadmu w glebie i ograniczenia pobierania tego metalu przez pszenicę jarą. Badania prowadzono w oparciu o doświadczenie mikropoletkowe założone w Stacji Doświadczalnej Instytutu Rolnictwa w Skierniewicach. Wierzchnią warstwę gleby zanieczyszczono kadmem doprowadzając ją do II stopnia zanieczyszczenia (1.87 mg Cd· $\mathrm{kg}^{-1}$ ) wg. Kabaty-Pendias i in. (1993). Glebę wapnowano CaO (60\%) w dawkach według 0, 0,5, 1,5 oraz 2 kwasowości hydrolitycznej (Hh). W doświadczeniu badaną rośliną była pszenica jara odmiany Mandaryn. W badaniach stwierdzono, że wraz ze wzrostem wapnowania zmniejsza się zawartość kadmu zarówno w ziarnie jak i w słomie pszenicy. Zawartość kadmu w ziarnie pszenicy wahała się od $0.038 \mathrm{mg} \mathrm{Cd} \cdot \mathrm{kg}^{-1}$ (2 Hh) do $0.351 \mathrm{mg} \mathrm{Cd} \cdot \mathrm{kg}^{-1}(0 \mathrm{Hh})$. Zawartość kadmu w słomie pszenicy wynosiła od $0.147 \mathrm{mg} \mathrm{Cd} \cdot \mathrm{kg}^{-1}$ (2 Hh) do $0.554 \mathrm{mg} \mathrm{Cd} \cdot \mathrm{kg}^{-1}$ (0 Hh). Zawartość kadmu w słomie nie przekroczyła dopuszczalnej zawartości substancji śladowych w paszach ustanowionych Rozporządzeniem Ministra Rolnictwa i Rozwoju Wsi z 2012 roku. 